\title{
CHROMOSOMES OF \\ THE PYCNOSCELUS INDICUS AND \\ P. SURINAMENSIS COMPLEX \\ (BLATTARIA: BLABERIDAE: PYCNOSCELINAE)*
}

\author{
By Louis M. Roth and Samuel H. Cohen \\ Pioneering Research Laboratory \\ U. S. Army Natick Laboratories \\ Natick, Massachusetts or 760
}

The chromosome numbers of both parthenogenetic and bisexual forms of Pycnoscelus surinamensis (L.) have been reported to be $38(P)$ and $37\left(O^{\pi}\right)$ by Matthey (1945, specimens from the botanical garden and crocodile house in Berlin; 1948, specimens from Kuala Lumpur, Malaya), and 36 (o parthenogenetic) by Suomalainen ( 1945 , specimens from the botanical garden and crocodile house in Berlin). Reproductive behavior (Roth and Willis, 1968), and crossing experiments (Roth, 1967) have shown that the parthenogenetic and bisexual "strains" are physiologically sexually isolated from one another and Roth (1967) applied the name Pycnoscelus indicus (F.) to the bisexual taxon from which the parthenogenetic form ( $P$. surinamensis) apparently arose. The specimens used in the 1967 study originated from Florida, Hawaii, Australia, and Indonesia. In this paper we report the results of a study of the numbers and morphology of the chromosomes of $P$. indicus, and clones of $P$. surinamensis from different geographical areas. Pycnoscelus surinamensis is cosmopolitan, whereas $P$. indicus appears to be restricted mainly to the Indo-Malayan region.

\section{MATERIALS AND METHODS}

The Pycnoscelus which were cultured in the laboratory originated from Florida, Jamaica, Panama, Brazil, Hawaii, Australia, Indonesia, and Thailand (see acknowledgements). It is possible that certain cytogenetic forms have been eliminated in those cultures of Pycnoscelus (e.g., from Florida and Australia) which have been kept for years in the laboratory. However, the specimens from Jamaica, Panama, Brazil, and Thailand were for the most part $F_{1}$ or $F_{2}$ offspring from the original material collected.

The methods used in preparing slides of mitotic figures were modifications of Tjio and Whang (1962) and Wolstenholme

*Manuscript received by the editor April 8, 1968 
(1966). Last instar nymphs were injected with twenty microliters of colcemid (in two instances adult parthenogenetic males were used), I6 to 24 hours later their gonads were dissected in an insect Ringer's solution (Bodenstein, 1946) and transferred to I \% sodium citrate solution for 5 to 7 minutes. The gonads were placed in acetic alcohol ( I part glacial acetic acid to 3 parts absolute alcohol) for about I minute, then in a drop of $45 \%$ acetic acid, on separate albuminized glass slides, until they became clear. Coverslips were placed over the gonads, squashed between 2 pieces of highly absorbent paper, and the slides were immediately placed on dry ice. After 5 to ro minutes, the coverslips were flipped off with a singleedged razor blade, and the slides were immediately placed in acetic acid-absolute alcohol ( $1: \mathrm{I})$ for Io minutes. The slides were quickly rinsed in absolute alcohol, placed in 2 changes of $95 \%$ alcohol for 5 minutes each, removed, and allowed to dry. A drop of aceticorcein was placed on the dried tissue, covered with a coverslip, and after about I minute, the excess stain was removed with absorbent paper. The slides were placed in 95\% alcohol, the coverslip was removed, the specimen rinsed in $95 \%$ alcohol, then in 2 changes of

Table 1. Chromosome numbers of Pycnoscelus indicus malesa.

\begin{tabular}{|c|c|c|c|c|c|c|}
\hline \multirow[b]{2}{*}{ Sourceb } & \multirow{2}{*}{$\begin{array}{l}\text { Nymph } \\
\text { Number }\end{array}$} & \multirow{2}{*}{$\begin{array}{c}\text { Cells } \\
\text { Examined }\end{array}$} & \multicolumn{4}{|c|}{$\begin{array}{l}\text { Number of cells with } \\
\text { the following chromosome counts: }\end{array}$} \\
\hline & & & 35 & 36 & 37 & 38 \\
\hline \multirow[t]{3}{*}{ Hawaiic } & 2 & 5 & 4 & & & 1 \\
\hline & 5 & 4 & 4 & & & \\
\hline & 6 & 12 & 12 & & & \\
\hline \multirow[t]{3}{*}{ Hawaiid } & 8 & 6 & 6 & & & \\
\hline & 11 & 17 & 15 & 1 & 1 & \\
\hline & $13^{e}$ & 3 & 3 & & & \\
\hline \multirow[t]{4}{*}{ Hawaiic } & 4 & 7 & 2 & 1 & 4 & \\
\hline & 7 & 6 & & & 6 & \\
\hline & 9 & 3 & & & 3 & \\
\hline & 10 & 9 & & & 9 & \\
\hline \multirow[t]{4}{*}{ Hawaiid } & 1 & 20 & 1 & & 19 & \\
\hline & 3 & 5 & & & 5 & \\
\hline & 12 & 20 & & & 20 & \\
\hline & $14 \mathrm{e}$ & 20 & 1 & 1 & 17 & 1 \\
\hline
\end{tabular}

aThe chromosomes in a maximum of 20 cells per individual were counted. If this number could not be found, as many cells as possible were examined. bThe original source from which laboratory colonies were started.

cFrom a culture of Hawaiian 우 $\times$ Hawaiian $\hat{o} \hat{o}$.

dFrom a culture of Bogor 우

eNymphs reddish. 
IOO\% alcohol for I minute each, and finally in xylene for about 5 minutes. Slides were made permanent by using a mounting medium such as Permount or Permaslip.

The photographs of the chromosomes (mitotic metaphase) were taken with Kodak Contrast Process Pan $4 \times 5$ sheet film. Development time was $3.5 \mathrm{~min}$ at $7 \mathrm{O}^{\circ} \mathrm{C}$ in Kodak D-I I. Enlargements were made up to $2600 X$ on Kodak Polycontrast paper.

For karyotyping, the photographs of the chromosomes were cut out and roughly arranged by type and size. Centromeric indices were then calculated and the values were used to place the chromosomes in their respective classes (Levan et al., I965). No attempt was made to pair the chromosomes and they are simply arranged by size, in each class.

\section{RESULTS AND DISCUSSION}

Pycnoscelus indicus. - The numbers of chromosomes found in $P$. indicus are summarized in Tables $\mathrm{I}$ and 2. Most of the specimens examined from our laboratory cultures have one of two modal diploid numbers of chromosomes: $2 \mathrm{n}\left(\sigma^{*}\right)=35$ or 37 (Table I ; Figs. I, 2 ) and $2 \mathrm{n}($ ( ) $)=36$ or 38 (Table 2 ; Figs. 3,4). Of the $2 \mathrm{I}$ female nymphs examined, only I had 37 chromosomes (Table 2, nymph no. I 8). It is possible that this female resulted from a cross between a male with $2 \mathrm{n}=35$ and a female with $2 \mathrm{n}=38$; a successful cross between these two forms should give females with 37 chromosomes.

Whether these 2 chromosomal forms exist in nature is unknown. The original $P$. indicus culture was started from several females originating in Hawaii in 1954, and additional specimens from the same island were added in 1958 (Roth, I967). It is possible that both forms were originally established in the laboratory; but it is also conceivable that one of the chromosomal forms arose during the I4 years that this culture has been maintained (approximately 25 generations - thousands of individuals were produced during this period). The scarcity of individuals with intermediate numbers of chromosomes, i.e., males with 36 (none were found among the I4 nymphs examined) and females with 37 chromosomes (only one found), suggests that the 2 chromosomal forms are not interbreeding successfully. There is apparently no way of distinguishing the 2 forms other than by chromosome count. Reddish or black nymphs may have either numbers of chromosomes (Tables I, 2, footnotes e and $\mathrm{f})$. We are attempting to establish separate cultures of the 
two chromosomal types (by rearing offspring from isolated females) for further study.

Pycnoscelus surinamensis. - Although Matthey (I945, I948) found that parthenogenetic $P$. surinamensis has the same number of chromosomes as the bisexual species, it is evident that the number of chromosomes in this complex is highly variable. The modal diploid numbers of chromosomes for the various clones of $P$. surinamensis (Table 3) are 34 (Brazil, Fig. 9; Australia, Fig. 5; Thailand, Fig. 8), 35 (Thailand, Fig. Io) 37 (Indonesia, Fig. I I), 53 (U.S., Fig. I3; Brazil, Fig. I5), and 54 (Panama, Fig. I6; Jamaica, Fig. I7).

Of 650 cells examined from one specimen from Bogor, Indonesia (normally with 37 chromosomes), 38 cells had 74 chromosomes, and

Table 2. Chromosome numbers of Pycnoscelus indicus femalesa.

\begin{tabular}{|c|c|c|c|c|c|c|c|c|c|}
\hline \multirow[b]{2}{*}{ Sourceb } & \multirow{2}{*}{$\begin{array}{l}\text { Nymph } \\
\text { Number }\end{array}$} & \multirow{2}{*}{$\begin{array}{c}\text { Cells } \\
\text { Examined }\end{array}$} & \multicolumn{7}{|c|}{$\begin{array}{l}\text { Number of cells with } \\
\text { the following chromosome counts: }\end{array}$} \\
\hline & & & 31 & 33 & 34 & 35 & 36 & 37 & $\overline{38}$ \\
\hline \multirow[t]{4}{*}{ Hawaiic } & 2 & 20 & & & & & 20 & & \\
\hline & 4 & 20 & & & & & 17 & & 3 \\
\hline & 5 & 20 & & & & & 20 & & \\
\hline & 8 & 20 & & 1 & & 2 & 15 & & 2 \\
\hline \multirow[t]{2}{*}{ Indonesia ${ }^{d}$} & $16 \mathrm{e}$ & 20 & & & & & 20 & & \\
\hline & $22^{f}$ & 20 & & & & 3 & 11 & 4 & 2 \\
\hline Indonesiad $^{d}$ & $18^{f}$ & 20 & 1 & & & 1 & 1 & 17 & \\
\hline \multirow[t]{7}{*}{ Hawaiic } & 1 & 20 & & & & & & & 20 \\
\hline & 3 & 20 & & & & & 2 & 1 & 17 \\
\hline & 6 & 20 & & & & & & & 20 \\
\hline & 7 & 20 & & & & & & & 20 \\
\hline & 9 & 20 & & & & & 1 & 3 & 16 \\
\hline & 10 & 20 & & & & 2 & 2 & 1 & 15 \\
\hline & 13 & 20 & & 1 & & & & 2 & 17 \\
\hline \multirow{7}{*}{ Indonesiad } & 11 & 20 & & & & & & & 20 \\
\hline & 12 & 13 & & & & & & & 13 \\
\hline & 14 & 20 & & & & & & & 20 \\
\hline & $15 \mathrm{e}$ & 20 & & & & & & & 20 \\
\hline & $17 \mathrm{e}$ & 15 & 1 & & 1 & 2 & & 1 & 10 \\
\hline & $20^{f}$ & 20 & & & & 3 & 4 & & 13 \\
\hline & $21^{f}$ & 20 & & & & & 4 & 4 & 12 \\
\hline
\end{tabular}

aThe chromosomes in a maximum of 20 cells per individual were counted. If this number could not be found, as many cells as possible were examined. bThe original source from which laboratory colonies were started.

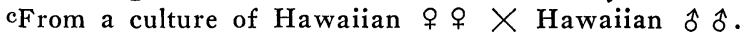

dFrom a culture of Bogor 우 $\times$ Hawaiian $\hat{o} \hat{o}$.

eNymphs reddish.

f Nymphs black. 


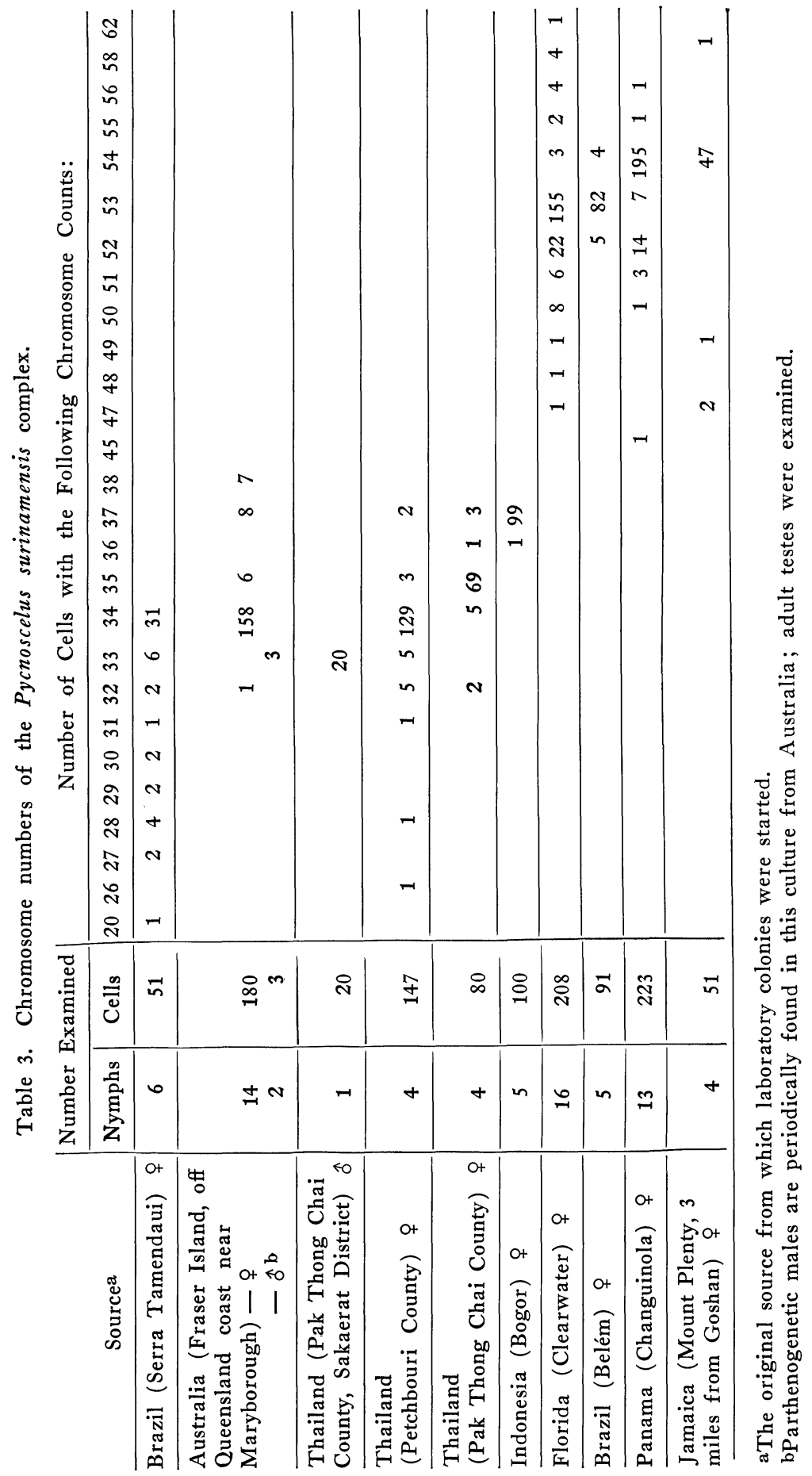


6 I 2 had the normal 37. In 63 cells of a female from Florida (normally 53 chromosomes), 40 were normal and 23 cells had 106 chromosomes. These 2 individuals which had some cells with double their normal number of chromosomes may possibly have resulted from the colcemid treatment.

None of our clones of $P$. surinamensis had modal numbers of 36 or 38 as reported by Suomalainen (1945) and Matthey (1945, 1948). These writers did not indicate the number of cells counted, so it is unknown if the numbers given by them are the usual numbers present. Considering the variation in the clones we examined, it is quite possible that the numbers they give predominated in the individuals of their colonies.

The types of chromosomes found in Pycnoscelus (Figs. I8-26) from different localities are summarized in Table 4. There are 3 classes of chromosomes: median, submedian, and subterminal. Median chromosomes predominate and usually there appear to be only I or 2 subterminals. The males of $P$. indicus have one less subterminal chromosome than their respective females. This is also true of the Thailand parthenogenetic male and suggests that the subterminal chromosomes may be the $\mathrm{X}$ chromosomes. However, arguing against this is the fact that the Bogor female appears to lack subterminals and the parthenogenetic females from Florida and Belém ( 53 chromosomes) lack one subterminal (Table 4), which should have made them males, if the subterminals were sex chromosomes and if these females have only $2 \mathrm{X}$ chromosomes. In addition, if the Panama and Jamaica clones are triploids, the females should have $3 \mathrm{X}$ chromosomes, and they apparently have only 2 subterminals (Table 4). It should be pointed out that several sources of error may affect the categorizing of some of the chromosomes. Not only may colcemid treatment affect the relative lengths of the arms because of contraction (Sasaki, I96I), but some of the chromosomes are so small that errors could be made in determining the location of the centromeres, and also in measuring the lengths of the arms. Most of the median chromosomes are readily classified, but there are some chromosomes which are on the borderline of the 3 categories.

In $P$. indicus some individuals have 2 less chromosomes than others. There is no way of telling whether the parthenogenetic forms arose from bisexual stocks with $2 n=36$ or 38 chromosomes (Table 5). For example, the Brazilian and Australian forms (34 chromosomes) may have lost 2 submedians if they came from a $2 n=36$ o or, they may have lost 2 medians and 2 submedians if they came from a 
Table 4. Classification of the chromosomes of the Pycnoscelus complex.

\begin{tabular}{|c|c|c|c|c|c|}
\hline \multirow[t]{2}{*}{ Source } & \multirow{2}{*}{$\begin{array}{c}\text { Modal } \\
\text { Numbers } \\
\text { of } \\
\text { Chromo- } \\
\text { somes }\end{array}$} & \multicolumn{3}{|c|}{ Number a of: } & \multirow[t]{2}{*}{ Figures } \\
\hline & & Median & $\begin{array}{c}\text { Sub- } \\
\text { median }\end{array}$ & $\begin{array}{c}\text { Sub- } \\
\text { terminal }\end{array}$ & \\
\hline \multicolumn{6}{|l|}{ P. indicus (Hawaii) } \\
\hline$\hat{o}$ & 37 & 22 & 14 & 1 & 2 \\
\hline q & 38 & 22 & 14 & 2 & 4,19 \\
\hline$\hat{o}$ & 35 & 20 & 14 & 1 & 1 \\
\hline 우 & 36 & 20 & 14 & 2 & 3,18 \\
\hline \multicolumn{6}{|l|}{$\begin{array}{l}\text { P. surinamensis } \\
\text { Thailand (Pak Thong Chai }\end{array}$} \\
\hline County, Sakaerat District) & 33 & 20 & 12 & 1 & 7,23 \\
\hline Brazil (Serra Tamendaui) & 34 & 20 & 12 & 2 & 9,20 \\
\hline Australia & 34 & 20 & 12 & 2 & 5,22 \\
\hline \multicolumn{6}{|l|}{ Thailand (Pak Thong Chai } \\
\hline County) & 35 & 20 & 13 & 2 & 10,21 \\
\hline Indonesia (Bogor) & 37 & 20 & 17 & 0 & 11,25 \\
\hline Florida & 53 & 36 & 16 & 1 & 13,26 \\
\hline Brazil (Belém) & 53 & 36 & 16 & 1 & 15 \\
\hline Panama (Changuinola) & 54 & 28 & 24 & 2 & 16,24 \\
\hline Jamaica & 54 & 28 & 24 & 2 & 17 \\
\hline
\end{tabular}

aTerminology after Levan et al. (1965). Other nomenclature systems refer to the 3 classes of chromosomes as metacentric (= median), submetacentric (= submedian), and acrocentric (= subterminaij).

$2 n=38$ stock. It is possible that the missing chromosomes may have been incorporated into other chromosome sets by translocation. The 2 forms with 53 and 54 chromosomes are of interest because they apparently differ markedly in their chromosomal morphology. It is likely that these arose from parthenogenetic females rather than a diploid bisexual stock. Females with 53 chromosomes (Florida and Belém) apparently have one less subterminal than those with 54 chromosomes (Panama and Jamaica). However, they differ markedly in that the Floridian and Brazilian females have 8 more medians and 8 less submedians than the Panamanian and Jamaican forms. This suggests that the 2 clones probably arose independently from different stocks; i.e., clones with 53 chromosomes did not necessarily arise from a form with 54 chromosomes like those found in the Panama and Jamaica clones, simply by a loss of one subterminal.

The results confirm White's suggestion (in Roth 1967) that there could be several thelytokous biotypes of $P$. surinamensis related to the bisexual taxon of $P$. indicus. $P$. surinamensis is polymorphic, cytogenetically diverse, and probably arose polyphyletically by poly- 
Table 5. Expected and observed diploid and triploid numbers of chromosomes in the P. surinamensis complex.

\begin{tabular}{c|cc}
\hline $\begin{array}{c}\text { n complement of } \\
\text { the bisexual } \\
\text { taxon }(P \text {. indicus })\end{array}$ & $\begin{array}{c}\text { Expected diploid and polyploid numbers } \\
\text { of chromosomes in } P \text {. surinamensis }\end{array}$ \\
\cline { 2 - 3 } 18 & $2 \mathrm{n}$ & $3 \mathrm{n}$ \\
19 & 36 & 54 \\
38 & 57 \\
& $\begin{array}{c}\text { Modal number of chromosomes observed in } \\
\text { parthenogenetic clones } \\
34(-2 \text { or }-4)^{\text {a }}\end{array}$ \\
& $35(-1$ or -3$)$ & $53(-1$ or -3$)$ \\
& $37(+1$ or -1$)$ & $54( \pm 0$ or -3$)$ \\
\hline
\end{tabular}

aThe 2 numbers in parentheses indicate the deviation from the expected number if $\mathrm{n}=18$, or 19 in the bisexual taxon.

ploidy and/or aneuploidy. The 54 chromosome form could be considered to be a triploid of the bisexual 36 chromosome species $(\mathrm{n}=$ I8). The aneuploid forms may have resulted from a loss of chromosomes or from Robertsonian changes; unfortunately, some of the chromosomes are so small that it was impossible to determine if Robertsonian changes were involved.

The color of the adults and nymphs may differ considerably. Nymphs may vary from red to black and adults vary from blackish brown to almost solid black. The adults in clones with 34 chromosomes [Australia, Petchburi (Thailand), and Serra Tamendaui (Brazil) ] are the darker more blackish form. The relatively lighter colored adults from Belém (Brazil) (53), Florida (53), Jamaica and Panama (54) have high chromosome numbers. However, this correlation is not constant since the Bogor (Indonesia) nymphs are reddish and adults are reddish brown, but they have 37 chromosomes. It is interesting that both the Serra Tamendaui (34), and Belém (53) forms are found in Brazil (the 2 areas are more than a thousand miles apart) and the adults of these 2 clones differ in color, the latter being more lightly colored; the parthenogenetic forms with the low chromosome numbers are not restricted to the IndoMalayan region.

Roth (1967) found I I parthenogenetic males in his colony of $P$. surinamensis from Australia. We have since noted additional males periodically produced in this laboratory culture and it seems that males are produced more frequently, probably by non-disjunction of 


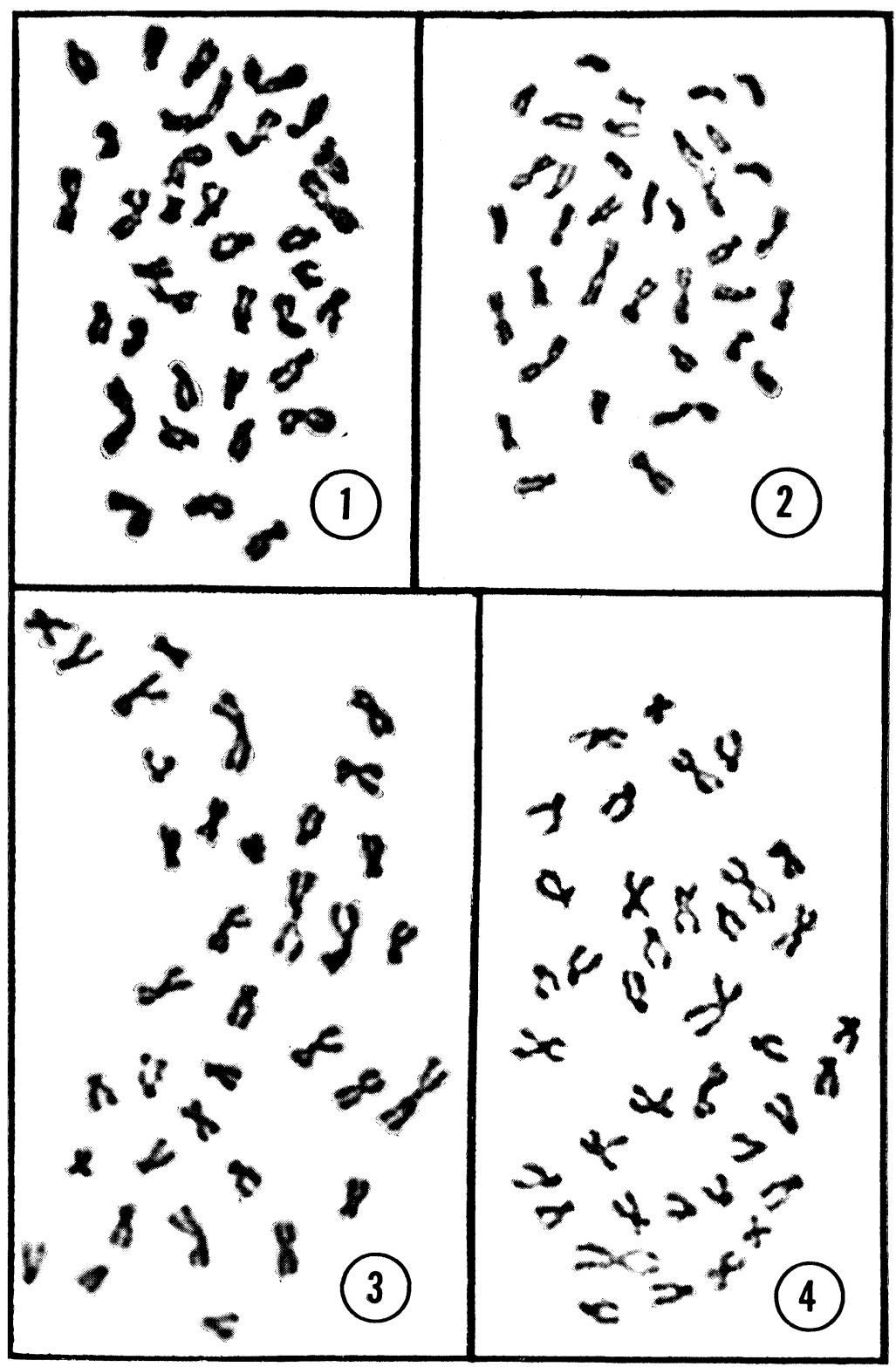

Figs. 1-4. Pycnoscelus indicus. Chromosomes of males and females from Hawaii $(X 1300)$. 1. ô $2 \mathrm{n}=35.2$. $\hat{o} 2 \mathrm{n}=37$. 3. ㅇ $2 \mathrm{n}=36$. 4. ㅇ $2 \mathrm{n}=38$. 
the $\mathrm{x}$ chromosome, by the Australian females than by Floridian females. Two of these Australian males had 33 chromosomes, as compared with 34 for the parthenogenetic female (Table I). No males have ever been observed in the Floridian culture in the more than I 5 years that this colony has been maintained. Seiler (I967) stated that in the moth Solenobia triquetrella F.R., the older and more stabilized the parthenogenesis becomes, the rarer are the males which are produced. Whether the occasional production of parthenogenetic males in the Australian colony indicates a more recent development (in nature) of parthenogenesis than the Floridian clone is unknown. Dr. Narbel-Hofstetter (personal communication) has suggested that if non-disjunction and therefore loss of an $\mathrm{x}$ chromosome occurred in the triploid form, the result would be $x x / a a a$ and not an $x / a a$ like that formed in the diploid clone. We have never seen intersexes in the triploid clones.

One male nymph from Thailand (Sakaerat District) had 33 chromosomes (Fig. 7). This was collected in the field and is presumed to be the parthenogenetic species whose female chromosome number is 34 (Table I, Fig. 8) or 35 (Table I, Fig. IO) in Thailand.

The parthenogenetic male from Australia (33 chromosomes; Fig. 6) and the Hawaiian males of $P$. indicus ( $2 \mathrm{n}=35$ or 37 ; Figs. I, 2) are non-functional when crossed with Floridian (53 chromosomes; Fig. 13) or Australian females (34 chromosomes; Fig. 5) (Roth, 1967). Thus, males of $P$. indicus or the occasionally produced males of $P$. surinamensis cannot introduce genes into the parthenogenetic population even though they mate with females; every parthenogenetic female is genetically isolated. This incompatability can be accounted for in $P$. surinamensis by the fact that its parthenogenesis is apomictic; although the parthenogenetic male undergoes meiosis, the diploid number is maintained in the female as a result of the absence of chromosome reduction (Matthey, I948), and amphimixis cannot occur (Seiler, 1967). The lack of success in crossing the parthenogenetic male with $P$. indicus may be explained by the difference in chromosome numbers between these two species.

The thelytokous parthenogenesis exhibited by $P$. surinamensis is not unique; White (I954) and Narbel-Hofstetter (I964) have listed several cytologically similar (polyploids and aneuploids) parthenogenetic species. Parthenogenesis in $P$. surinamensis conforms well with White's ( I954, p. 34I) statement that since no pairing of chromosomes takes place during maturation of the eggs in an apomic- 


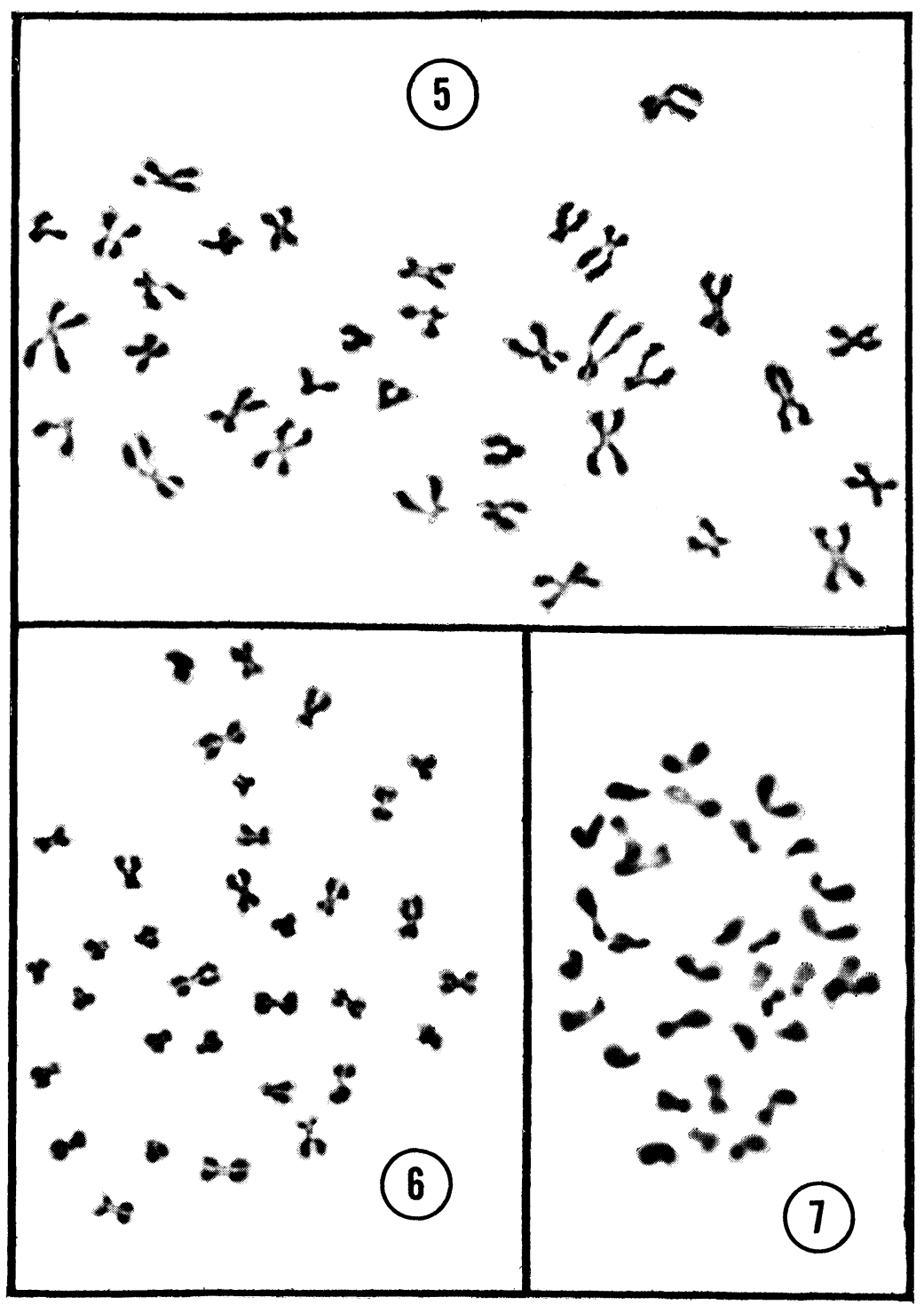

Figs. 5-7. Chromosomes of Pycnoscelus surinamensis $(X 1300)$. 5. Female from Australia, 34 chromosomes. 6. Male from Australia, 33 chromosomes. 7. Male from Pak Thong Chai County, Sakaerat District, Thailand, 33 chromosomes. 
tic species, ". . . there is no 'mechanical' barrier to the establishment of any type of polyploidy in such forms and various forms of aneuploidy, due to irregular reduplication of some chromosome elements, must be expected to occur."

\section{ADDENDUM}

Since this paper went to press we have obtained the following additional information concerning Pycnoscelus. Dr. Barbara Stay gave us several specimens of $P$. surinamensis which she collected in Queen Elizabeth Park, Lake Edward, Uganda, Africa. A colony has been established and there are 54 chromosomes in this clone $(20$ cells in 2 nymphs were examined). The number of chromosomes is the same as that found in the females from Jamaica and Panama. The African females also resemble the Jamaican and Panamanian forms in size, coloration, and wing length.

A colony of $P$. surinamensis was established from 2 adult females collected in Puraquequara, Rio Negro, Amazonas, Brazil. This clone has 39 chromosomes ( 40 cells from 4 female nymphs were examined).

We also crossed i6 P. surinamensis females from Bogor, Indonesia ( 37 chromosomes) with males of $P$. indicus from Hawaii (35 or 37 chromosomes). All the females had sperm in their spermathecae when they were examined after producing young. Two hundred and seven females were reared and these had 37 chromosomes like their mothers (50 cells from 5 nymphs which originated from 3 different females, were examined). Only one male was produced. However, this male had 35 chromosomes and one would expect it to have had 36 if it originated parthenogenetically. It is possible that the male was $P$. indicus which accidentally got into the container of nymphs being reared.

\section{SUMMARY}

The bisexual species $P$. indicus, from which the parthenogenetic species $P$. surinamensis apparently arose, has chromosomal polymorphism and is $2 \mathrm{n}\left(\mathrm{O}^{\mathrm{x}}\right)=35$ and 37 , and $2 \mathrm{n}($ o $)=36$ and 38 . Parthenogenetic Pycnoscelus surinamensis is cytogenetically polymorphic, probably arose polyphyletically, and may be aneuploid or polyploid. The modal numbers of chromosomes of $P$. surinamensis are 34 (Brazil. Australia, Thailand), 35 (Thailand), 37 (Indonesia), 39 (Brazil), 53 (U.S., Brazil), and 54 (Panama, Jamaica, Africa). 


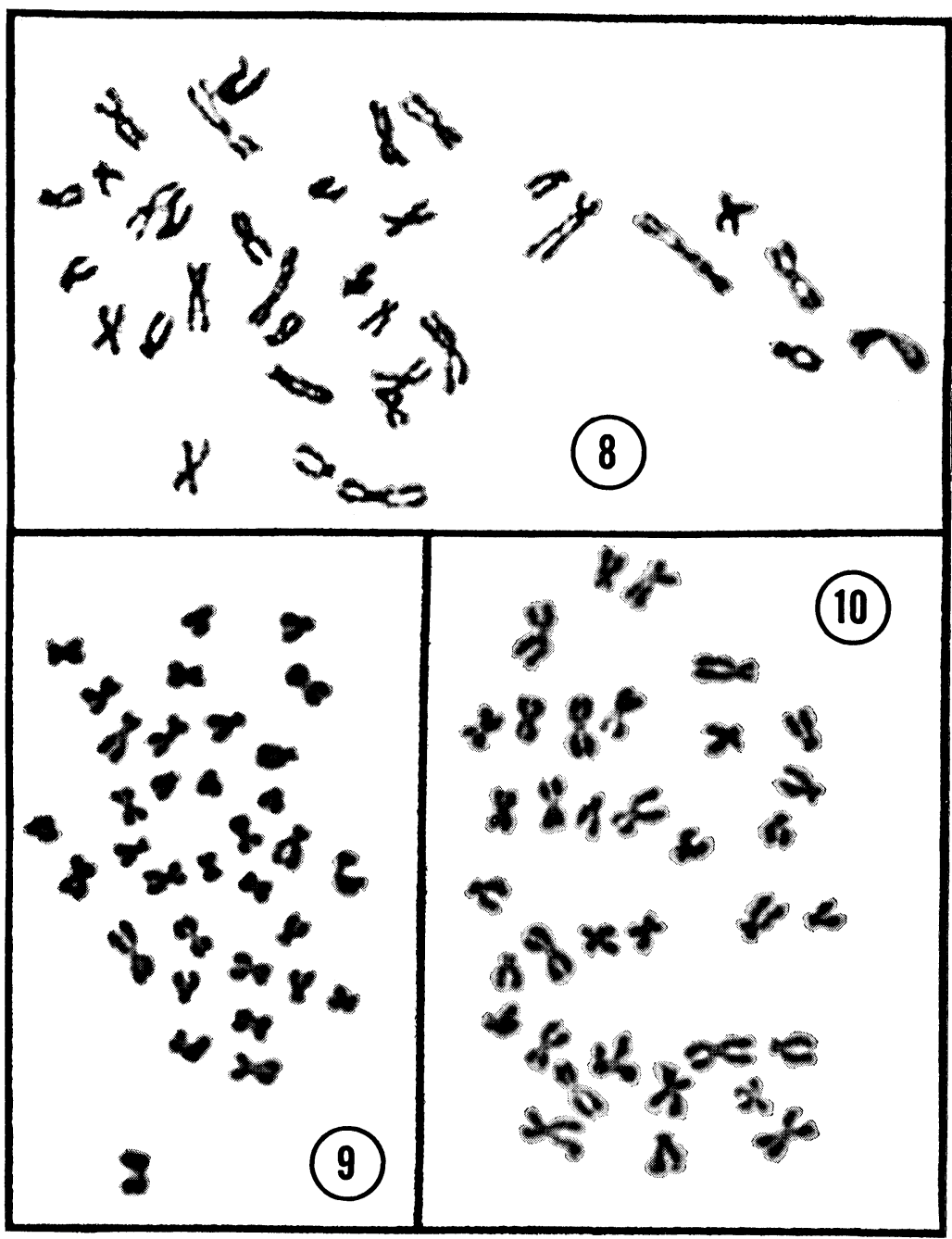

Figs. 8-10. Pycnoscelus surinamensis. Chromosomes of females $(X 1300)$. 8. From Petchburi County (Thailand), 34 chromosomes. 9. From Serra Tamendaui (Brazil), 34 chromosomes. 10. From Pak Thong Chai County (Thailand), 35 chromosomes. 


\section{ACKNOWLEDGEIMENTS}

We thank the following for supplying living Pycnoscelus: Dr. M. J. Mackerras (Australia), Dr. S. Kadarsan (Indonesia), Mr. Clyde Stephens (Panama), and Mr. Marc Roth (Jamaica).

The Thailand specimens were collected by L. M. Roth and Mr. Noel Kobayashi during a 6-week collecting trip in connection with Project TREND (TRopical ENvironmental Data) for ARPA (Advanced Research Projects Agency). We thank the Applied Scientific Research Corporation of Thailand for the use of their facilities. The Brazilian specimens were collected by L. M. Roth during Phase $\mathrm{C}$ of the Alpha Helix Expedition to the Amazon; we are grateful to the National Science Foundation for support on the Amazon Expedition under grant NSF-GB-5916.

We are indebted to Dr. M. J. D. White, Dr. Guy Bush, Dr. M. Narbel-Hofstetter and Dr. W. Prensky for their helpful suggestions.

Bodenstein, D.

\section{REFERENCES}

1946. Investigation of the locus of action of DDT in flies (Drosophila). Biol. Bull. 90 : 148-57.

Levan, A., K. Fredga, And A. A. SAndberg.

1965. Nomenclature for centromeric position on chromosomes. Hereditas, 52: 201-20.

MatThey, R.

1945. Cytologie de la parthénogénèse chez Pycnoscelus surinamensis L. (Blattariae-Blaberidae-Panchlorinae). Rev. Suisse Zool. 52: 1100.

1948. La formule chromosomiale de la race bisexuée de Pycnoscelus surinamensis $\mathrm{L}$., comparée à celle de la race parthénogénétique. Experientia, 4: 304-11.

NARbel-Hofstetter, $M$.

1964. Les alterations de la méiose chez les animaux parthénogénétiques. Protoplasmatologia, 6: 1-163.

RoTH, L. M.

1967. Sexual isolation in parthenogenetic Pycnoscelus surinamensis and application of the name Pycnoscelus indicus to its bisexual relative (Dictyoptera: Blattaria: Blaberidae: Pycnoscelinae). Ann. Entomol. Soc. Amer. 60: 774-9.

Roth, L. M. AND E. R. Willis.

1961. A study of bisexual and parthenogenetic strains of Pycnoscelus surinamensis (Blattaria, Epilamprinae). Ann. Entomol. Soc. Amer. 54: 12-25.

SASAKI, M.

1961. Observations on the modification in size and shape of chromosomes due to technical procedure. Chromosoma, 11: 514-522. 


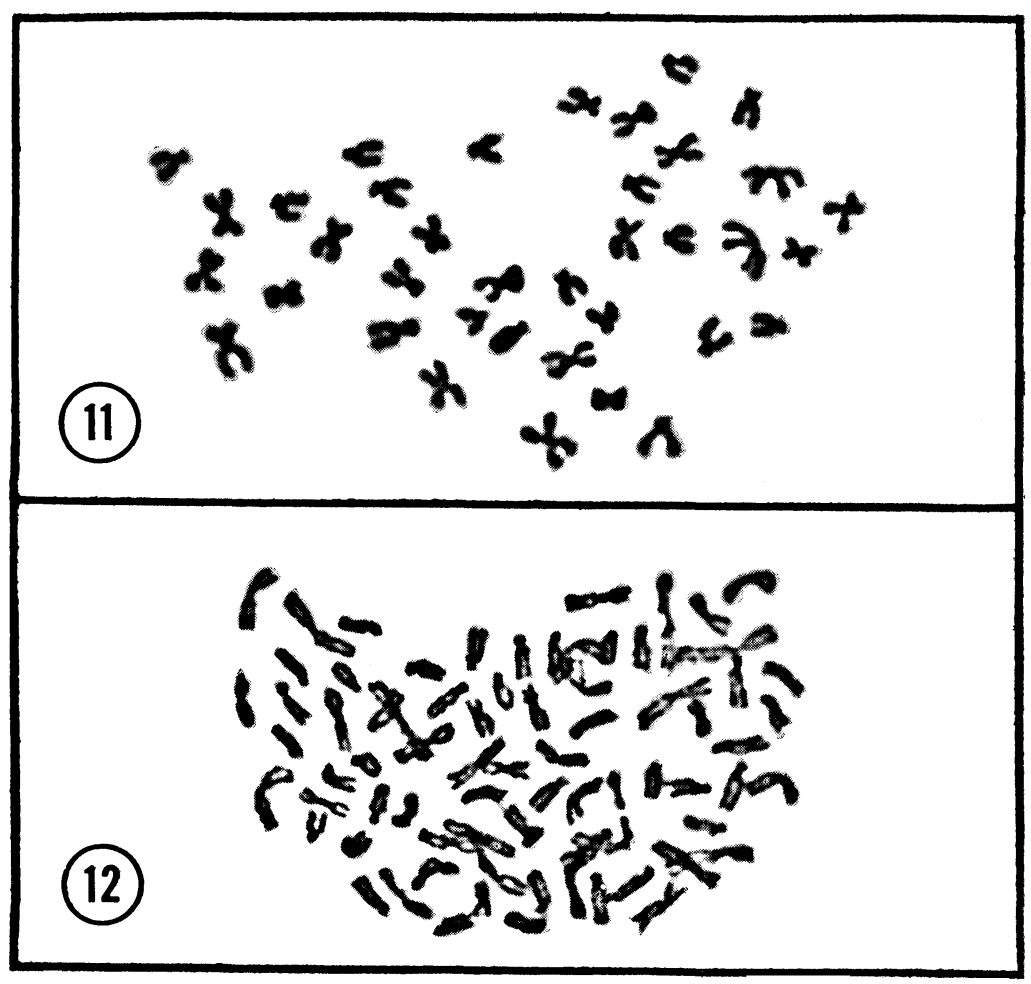

Figs. 11-12. Pycnoscelus surinamensis. Chromosomes of females from Bogor (Indonesia). 11. 37 chromosomes $(X 1300)$. 12. 74 chromosomes $(X 1000)$. 
SEILER, J.

1967. Untersuchungen über die Entstehung der Parthenogenese bei Solenobia triquetrella F. R. (Lepidoptera, Psychidae). VII. Versuch einer experimentellen Analyse der Genetik der Parthenogenese. Molec. Gen. Genetics, 99: 274-310.

SuOMALAinen, E.

1945. Vermutete Triploidie bei der parthenogenetischen Gewächshausschabe, Pycnoscelus surinamensis L. (Blattaria). Hereditas, 31 : 501-4.

TJio, J. H. AND J. Whang.

1962. Chromosome preparations of bone marrow cells without prior in vitro culture or in vivo colchicine administration. Stain Tech., 37 : 17-20.

White, M. J. D.

1954. Animal cytology and evolution. Cambridge University Press. $454 \mathrm{pp}$.

Wolstenholme, D. R.

1966. Direct evidence for the presence of DNA in interbands of Drosophila salivary gland chromosomes. Genetics, 53: 357-60. 


\section{Explanation of Figures $13-26$}

Figs. 13-14. Pycnoscelus surinamensis. Chromosomes of females from Florida $(X 1300)$. 13. 53 chromosomes. 14. 106 chromosomes.

Figs. 15-17. Pycnoscelus surinamensis. Chromosomes of females $(X 1300)$. 15. Belém (Brazil), 53 chromosomes. 16. Changuinola (Panama), 54 chromosomes. 17. Jamaica, 54 chromosomes.

Figs. 18-19. Pycnoscelus indicus. Karyotypes of females from Hawaii $(X 2600)$. 18. $2 \mathrm{n}=36$. 19. $2 \mathrm{n}=38$.

Figs. 20-21. Pycnoscelus surinamensis. Karotypes of females $(X 2600)$. 20. Brazil (Serra Tamendaui), 34 chromosomes. 21. Thailand (Pak Thong Chai County), 35 chromosomes.

Figs. 22-23. Karotypes of Pycnoscelus surinamensis $(X 2600)$. 22. Female from Australia, 34 chromosomes. 23. Male from Thailand (Pak Thong Chai County, Sakaerat District), 33 chromosomes.

Figs. 24-25. Karyotypes of Pycnoscelus surinamensis females $(X 2600)$. 24. From Panama (Changuinola), 54 chromosomes. 25. From Indonesia (Bogor), 37 chromosomes.

Fig. 26. Karyotype of a female Pycnoscelus surinamensis from Florida, with 53 chromosomes. Top 3 rows are medians; fourth row, submedian; bottom row, subterminal $(X 2600)$. 


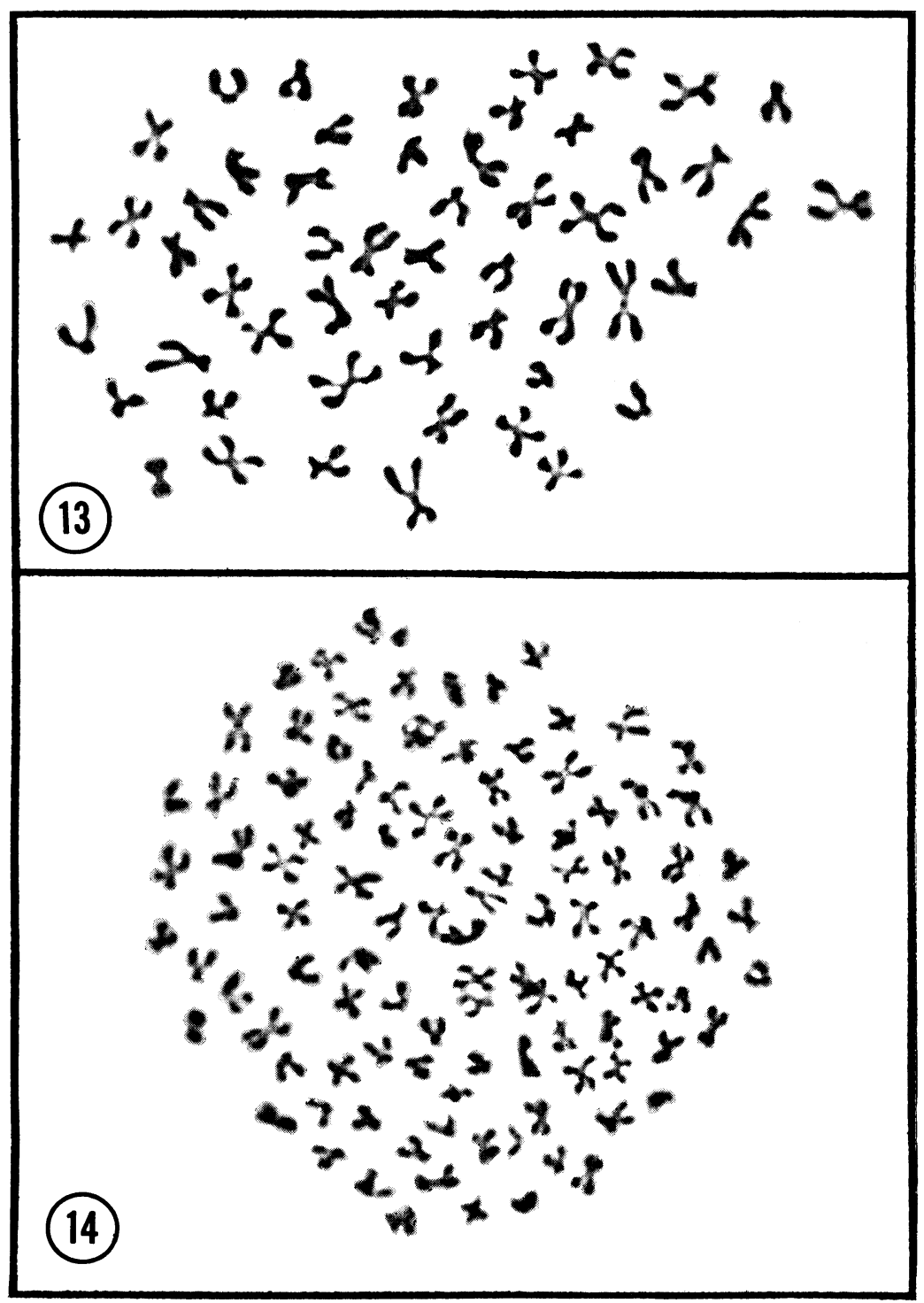




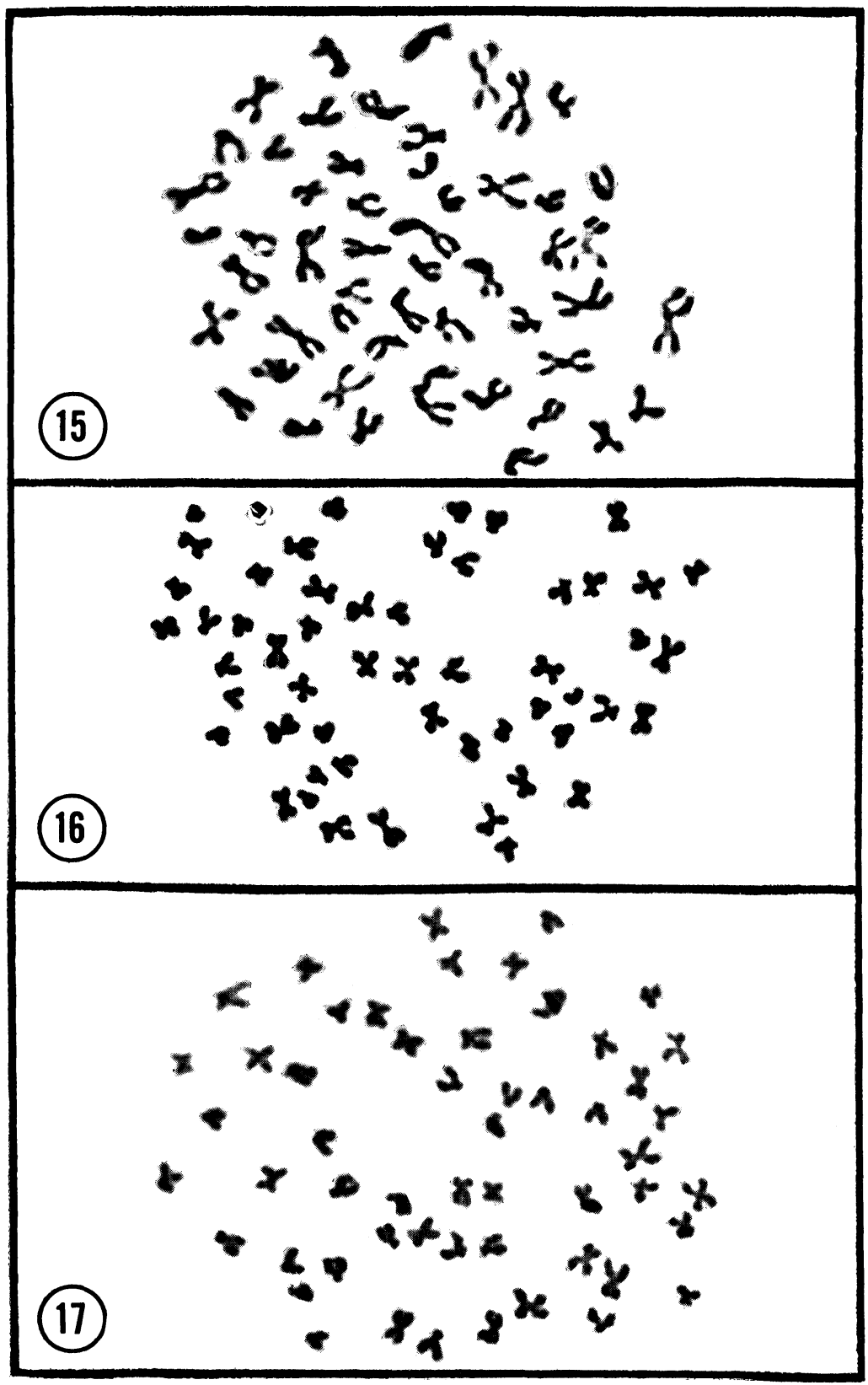




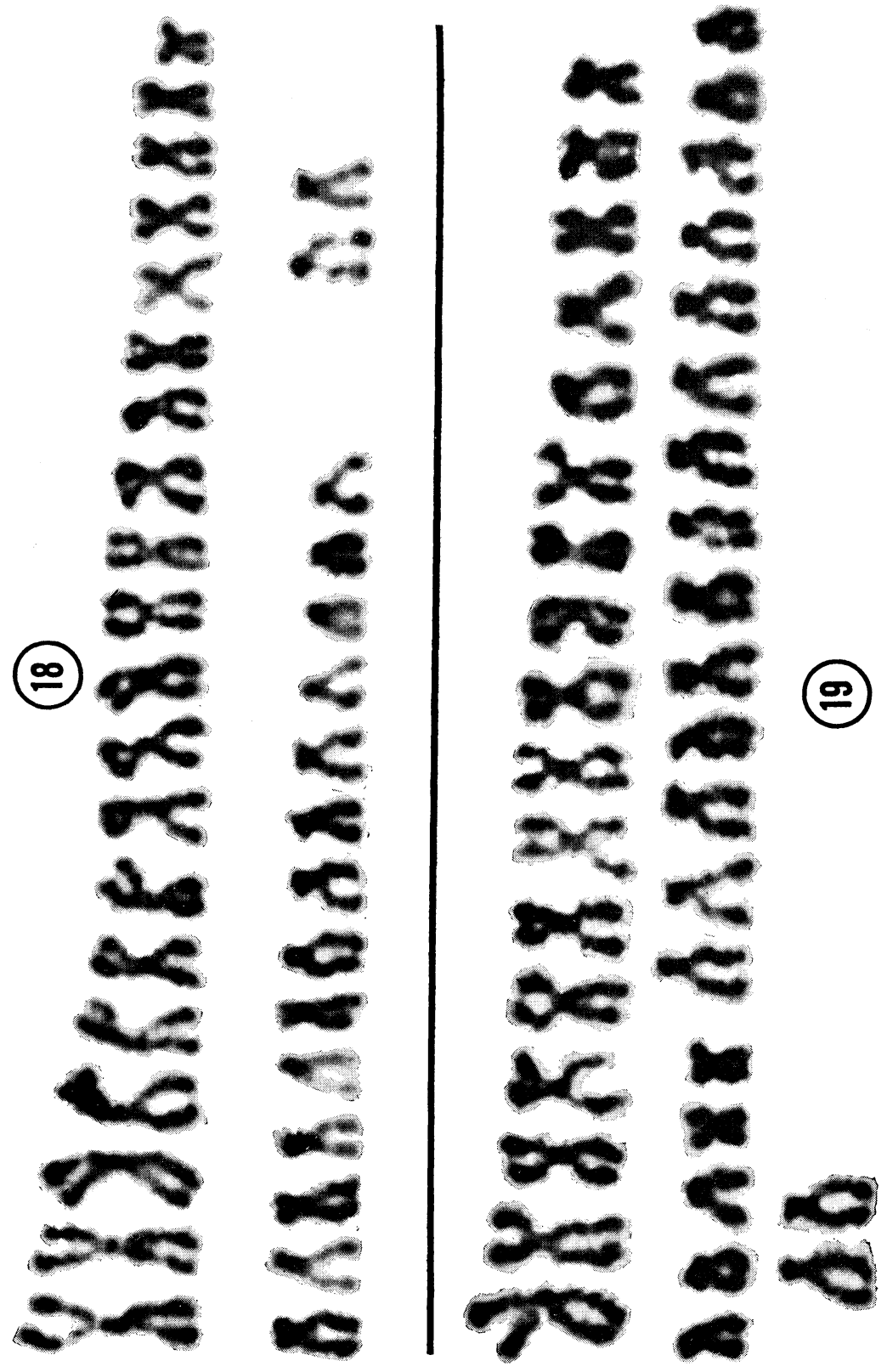




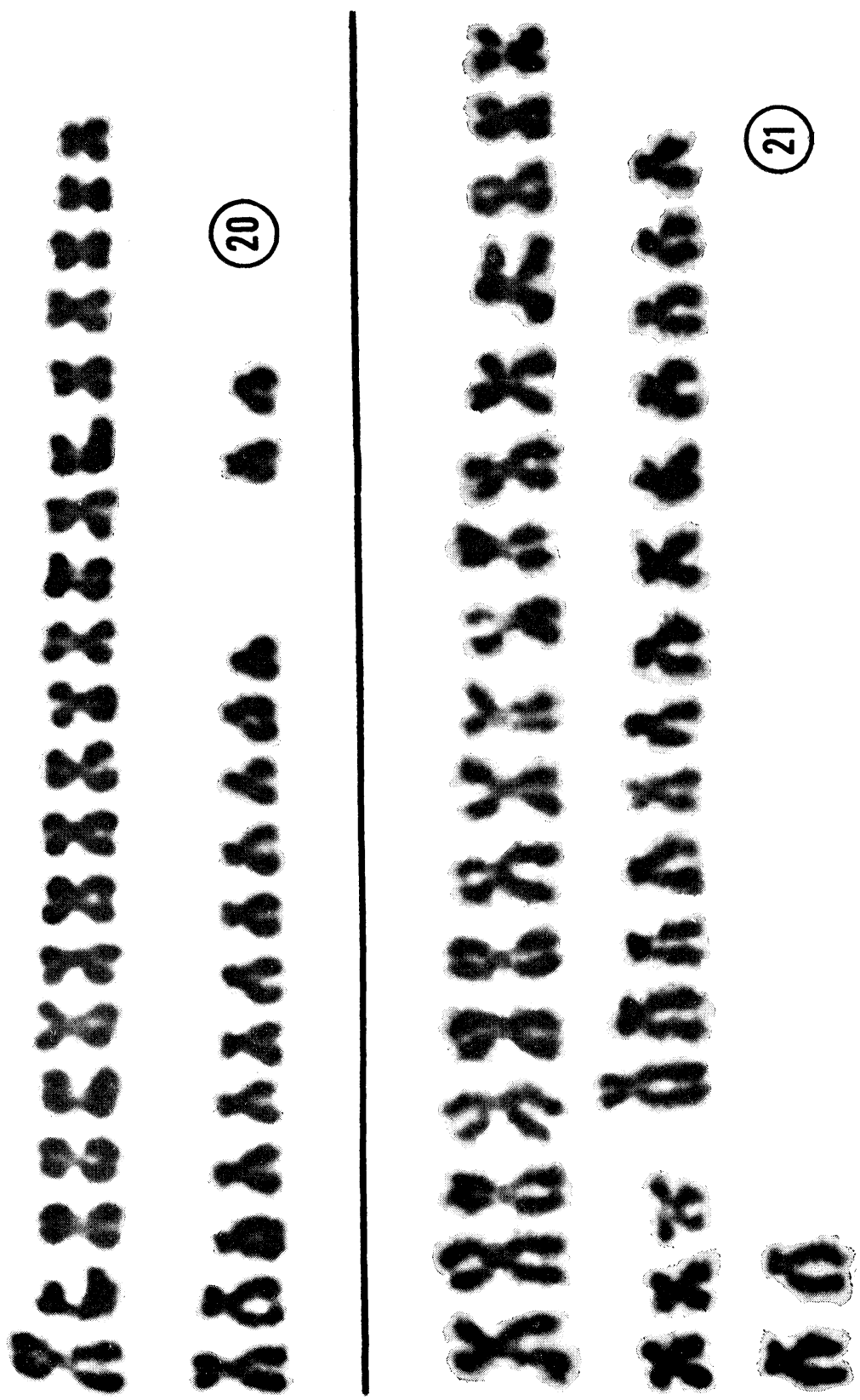




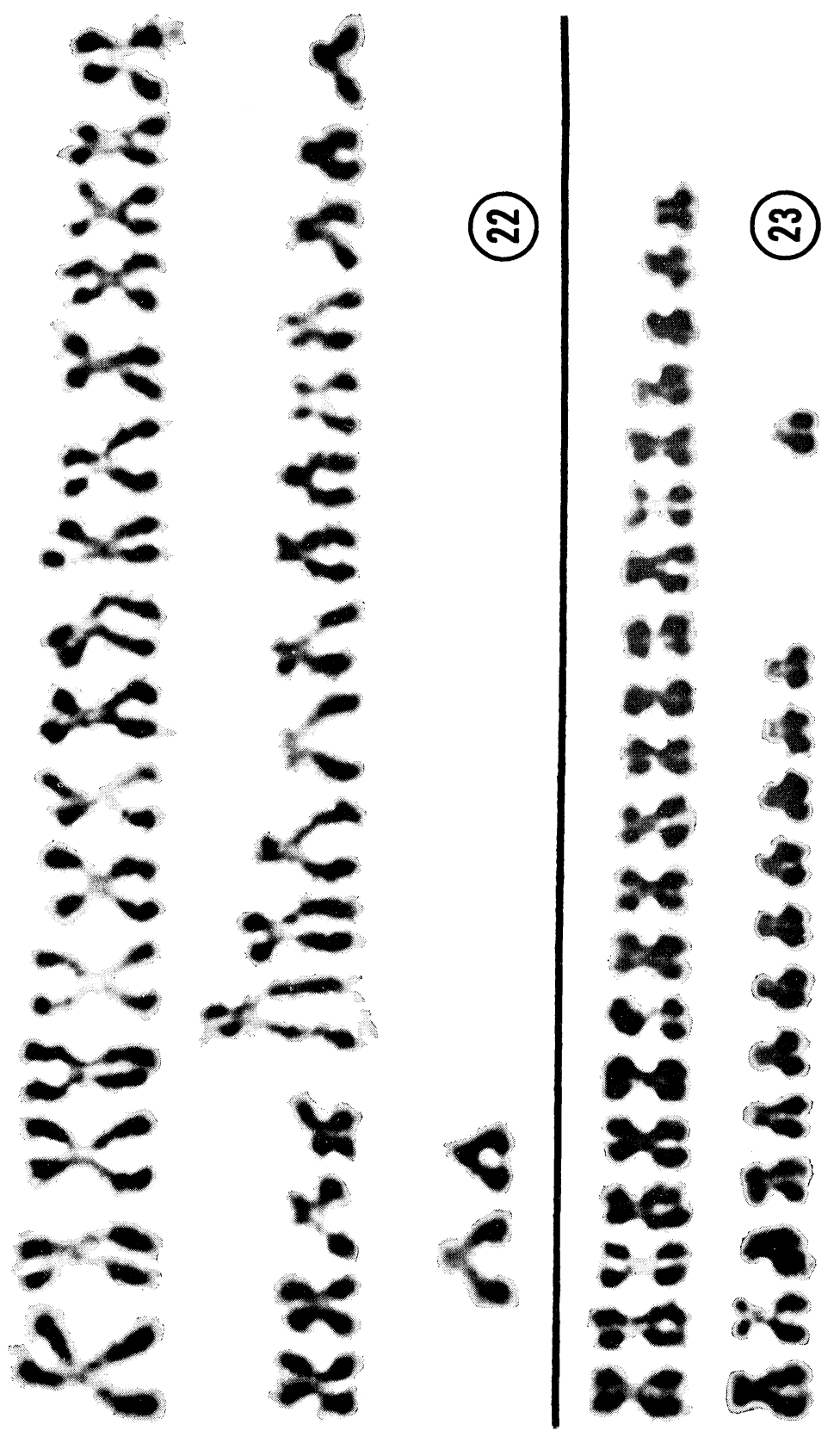




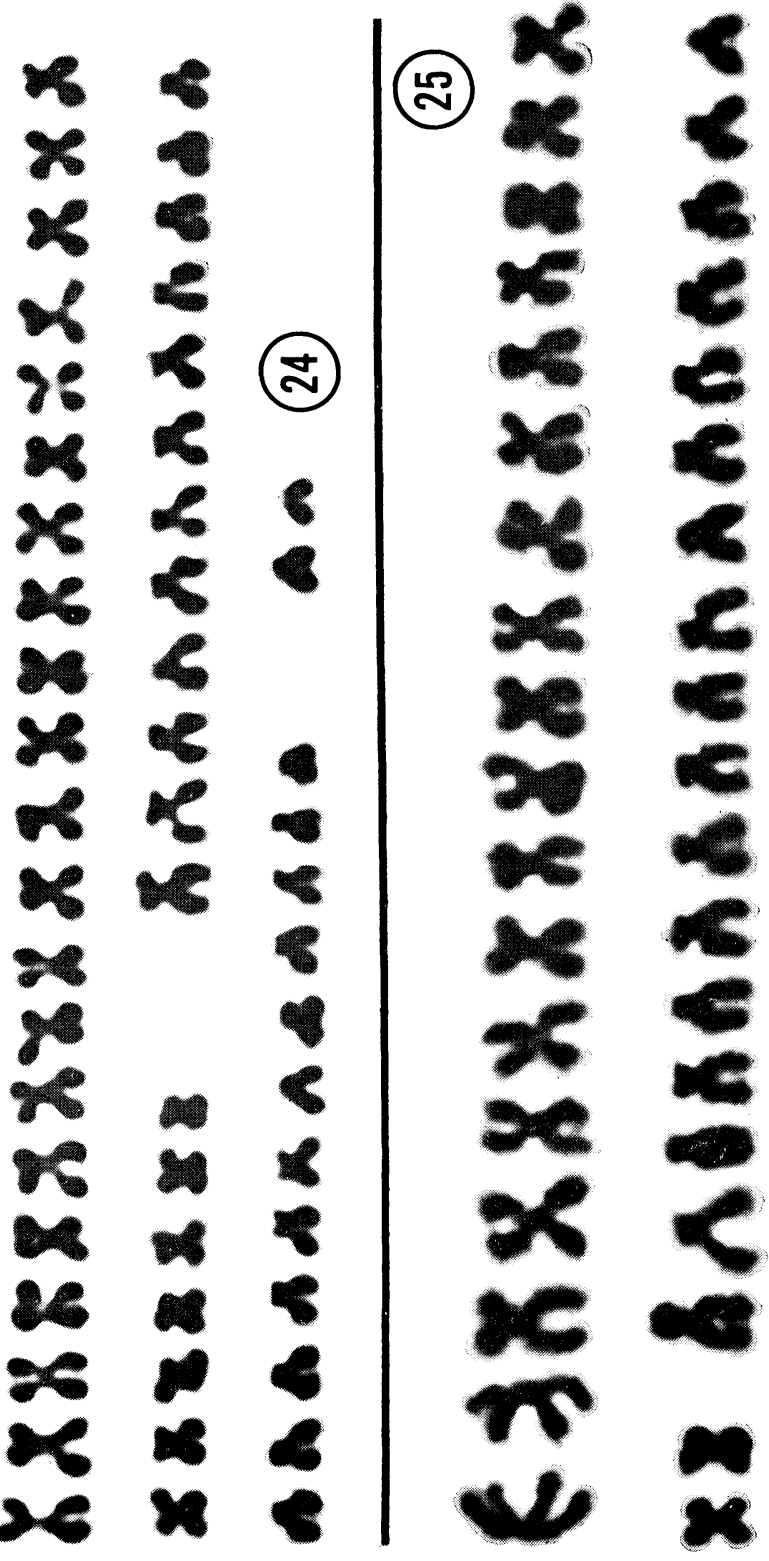




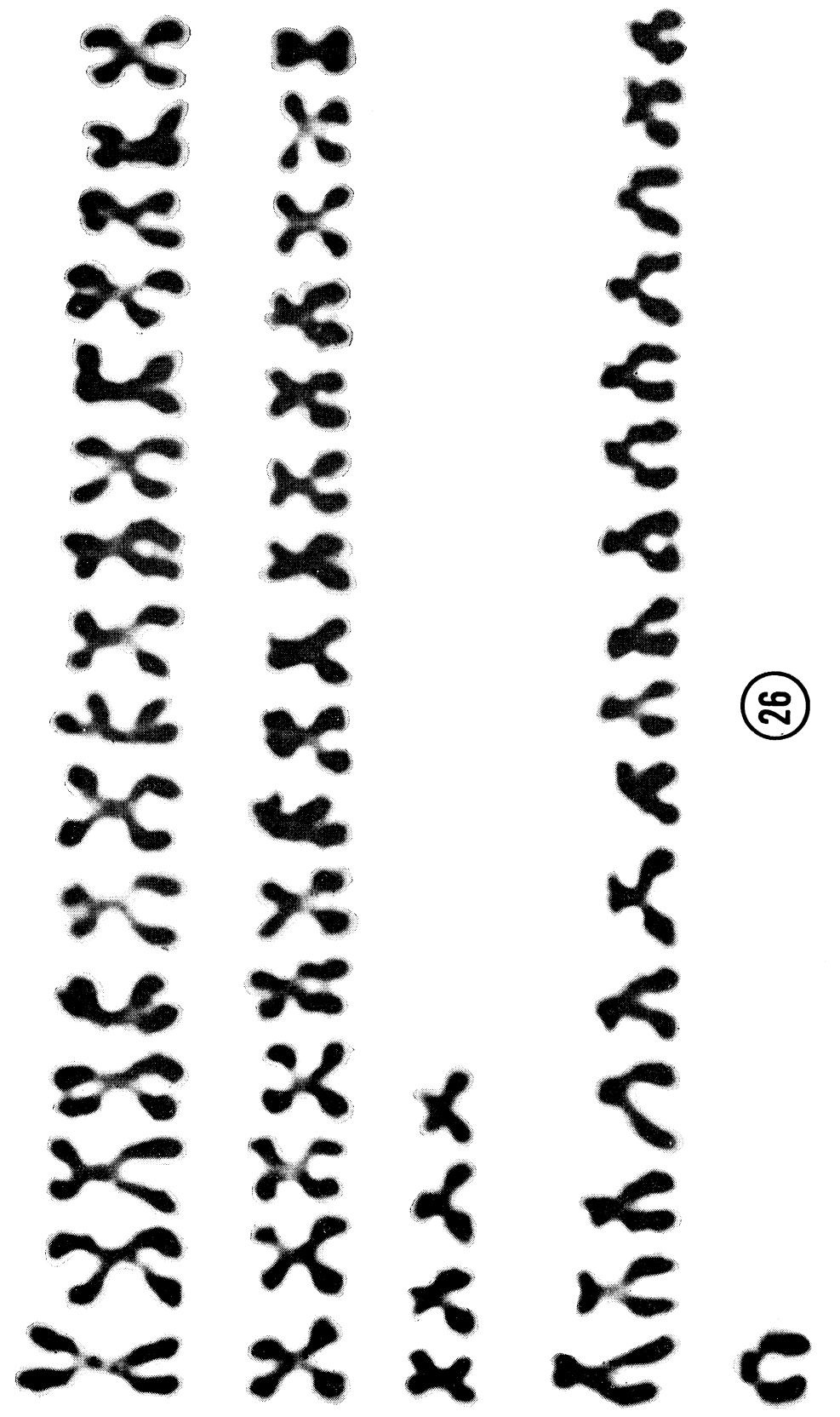



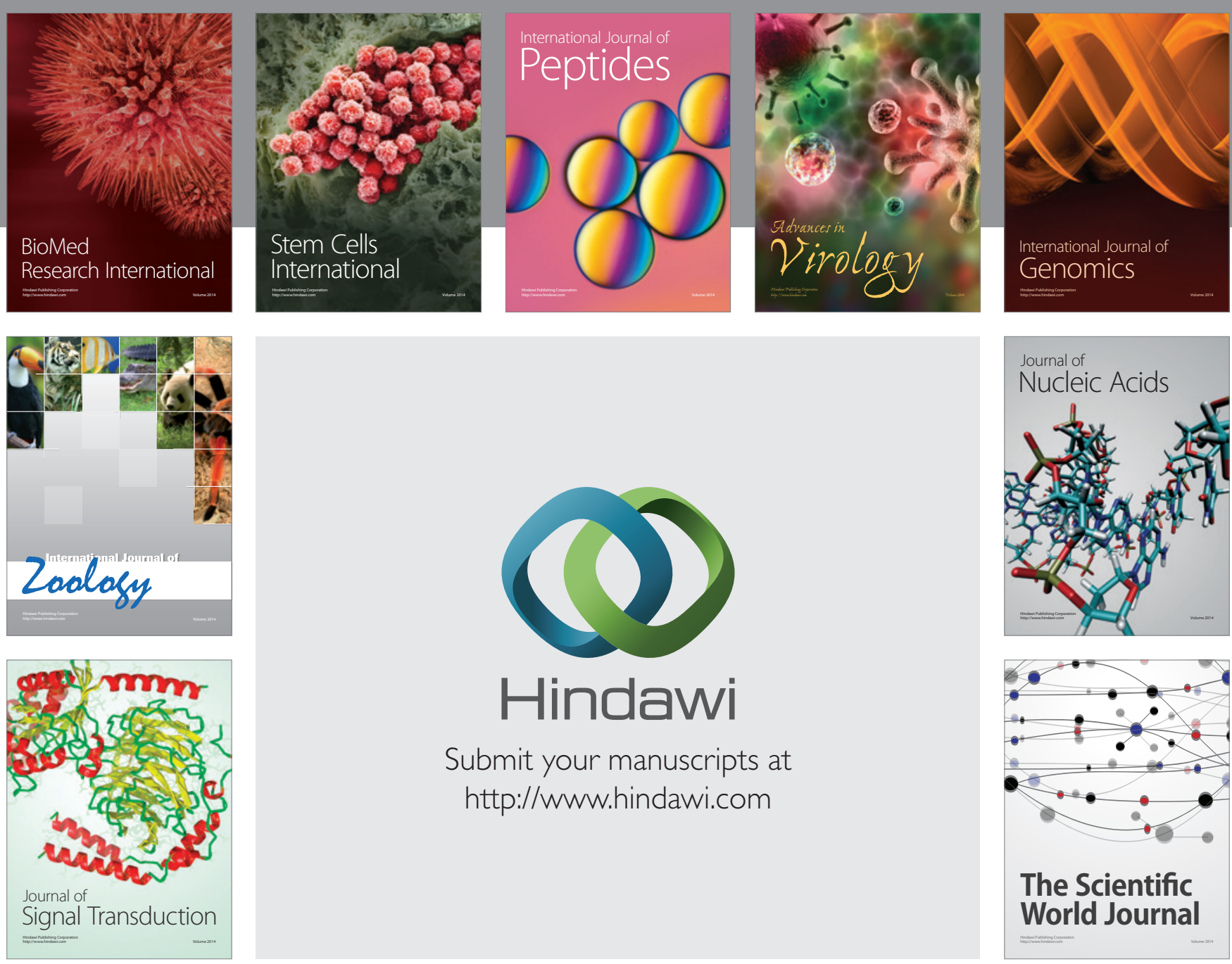

Submit your manuscripts at

http://www.hindawi.com
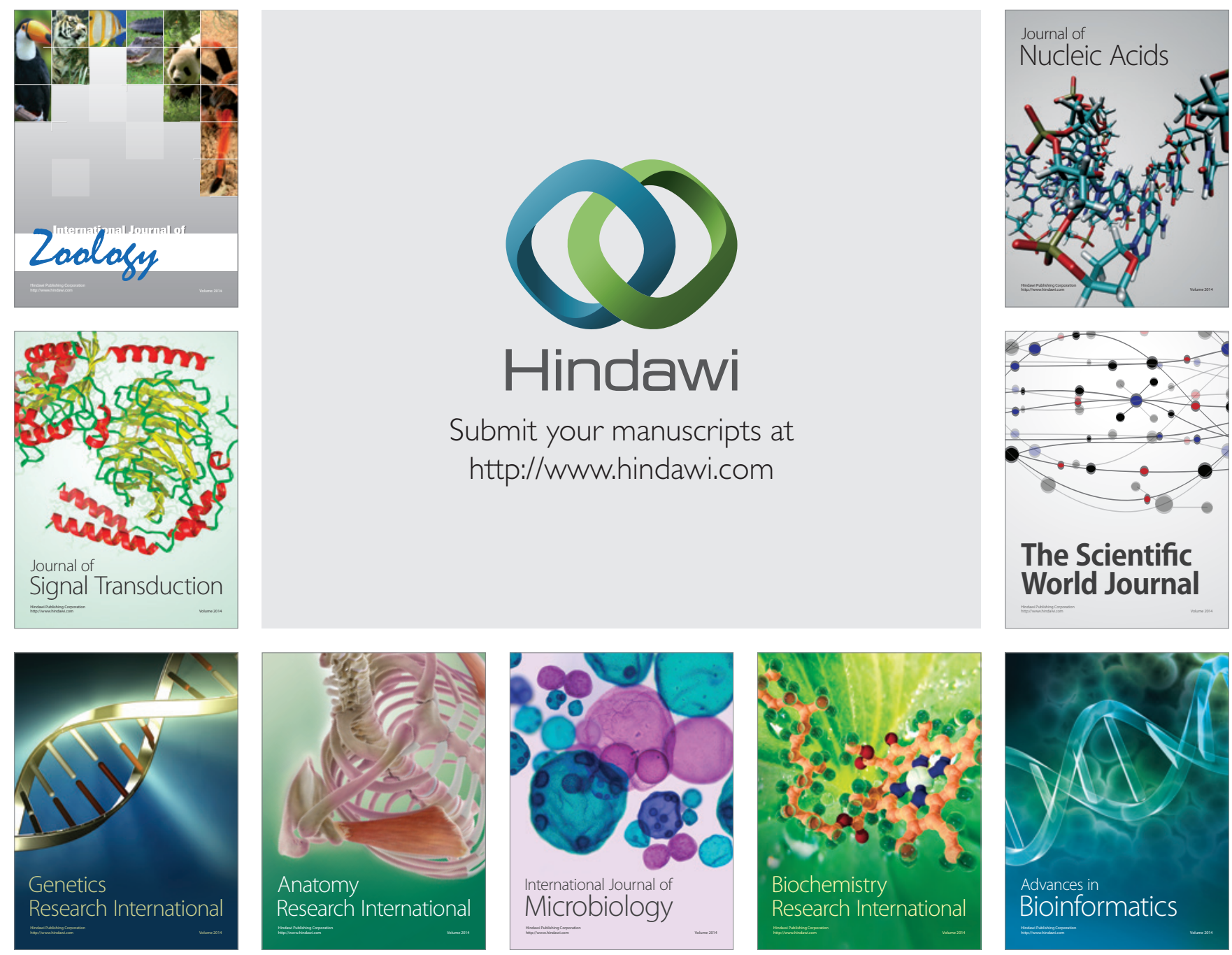

The Scientific World Journal
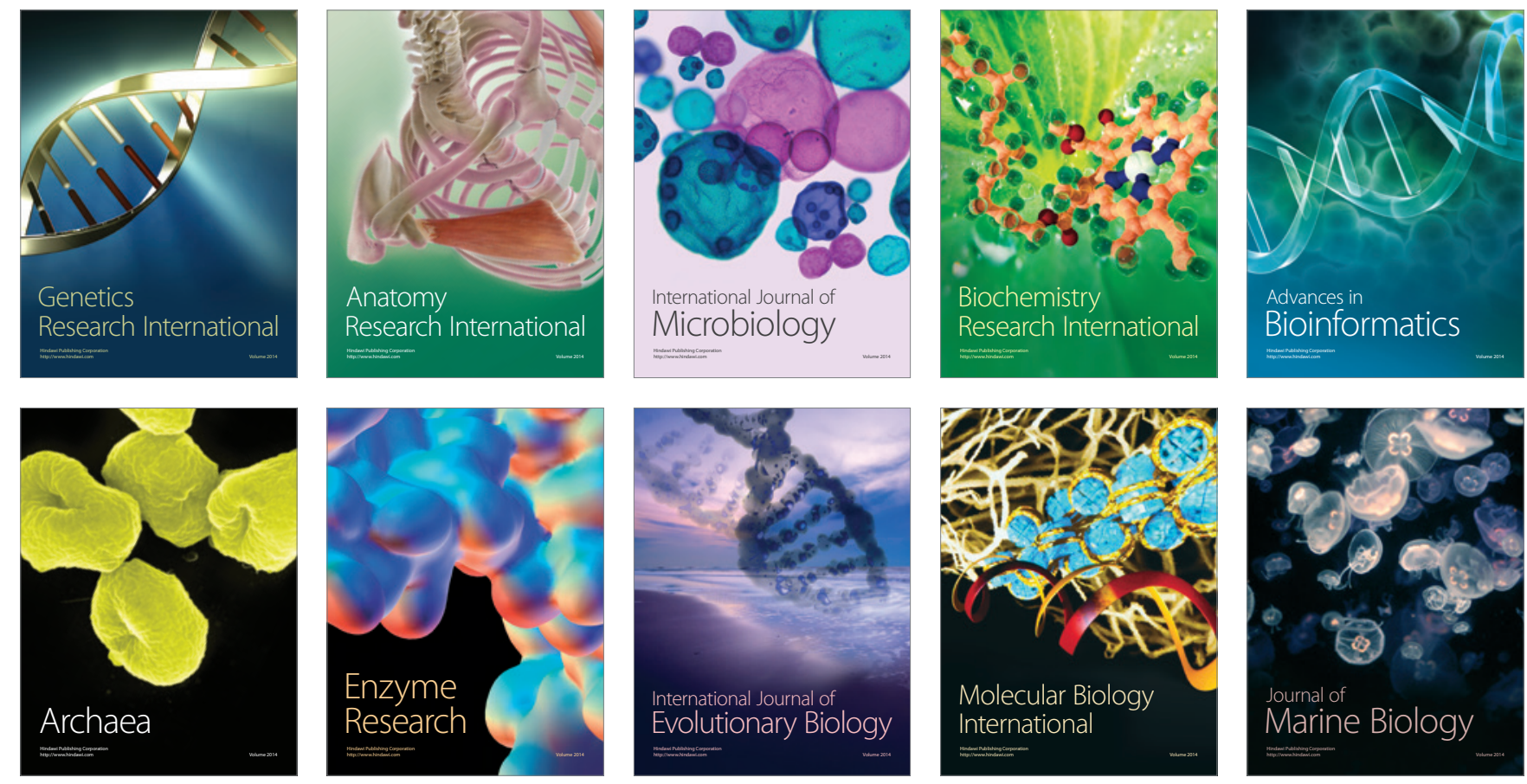